\title{
LEADER APPROACH EFFECTS IN THE RECONFIGURATION OF SOCIO-ECONOMIC STRUCTURES OF RURAL ENVIRONMENTS
}

\author{
Gabriel Nicolae PRICINĂ ${ }^{1}$ \\ DOI: 10.35782/JCPP.2019.3.03
}

\begin{abstract}
This article is the result of a research carried out in the period established by the European and national regulations for evaluating the implementation degree of the Local Development Strategies within the communities organized in Local Action Groups. Given that each evaluation targeted a Local Action Group, we resorted to centralize the data to identify the positive and negative evaluations regarding the LEADER approach and the Local Development Strategies. The results of the data centralization of the three Local Action Groups included in this research reveal opinions regarding the strengths and weaknesses of the Local Development Strategies, and highlight the general factors that favor and inhibit the local development. Also, the analysis of the centralized data allows the distinction between the opinions due to the local specific and the general ones that are correlated with the European regulations and the national strategies. This distinction makes it possible to clarify the logic of local interventions so that local initiatives are not affected by measures that ignore local and regional resources.
\end{abstract}

Key words: rural development, LEADER method, emigration, poverty, demographic decline

\section{Introduction}

Efforts to solve complex problems in the Romanian rural area have diversified the intervention methods. The analysis of the effects of the policies implemented over time revealed the impossibility of the isolated action over different communities in meeting the needs. The resources of communities with small populations, geographically located at great distances from cities, with predominantly agricultural activities and with a minimum stock of human, social and economic capital, are insufficient in implementing policies based on community participation. Thus, Local Action Groups have become a means by which local initiatives can be coagulated to solve common problems. Funding

1 Lecturer, PhD, University of Craiova, Faculty of Social Sciences; E-mail: gabrielpricina@ gmail.com. 
sources are provided for the projects of those entities consisting of several small communities. The extent to which these associations have satisfactory results and have the capacity to develop an overview of the geographical area in which they exist is an object of analysis. Questions about the surplus-value generated by the implemented projects, the adequacy of the financing, the sustainable vision and the clarity of the local development strategies become logical, given the unfavorable statistics of Romania compared to the developed states of Europe.

On such a background, this study is part of the evaluation of the Local Development Strategies of three Local Action Groups in Oltenia: "Colinele Olteniez", "La Noi în Sat" and "Tinutul Closani". This activity is regulated by the organization of the LEADER method, of the European and national documents and regulations. The recommendations resulting from such external evaluations are set as reference points for future project modifications and improvements. Unequal results have been identified as a result of the evaluation. The attention given to all the components of the Development Strategies is insufficient due to funding that does not cover all aspects and which generates a lower dynamic in relation to the dynamics of development at a European level. The conclusions and observations in this article are based on the secondary analysis of centralized data from those involved in projects using the LEADER method.

\section{Theoretical Benchmarks}

Debates about the existence of methods, strategies or policies tend to standardize various approaches without guaranteeing success in all areas of implementation. The reasons related to the objective of granting the financial support involve the elaboration of strategies generated by the identified needs and the configuration of the budgets based on the needs. The difficulty results in the differences between the theoretical principles, which are favorable to the "top-down" approach and the territorial problems that require a "bottom-up" approach.

Mostly the theoretical approaches are characterized by an evolutionary model, based on which development strategies should be realized. The LEADER approach seeks to initiate "bottom-up" policies in order to increase the involvement degree of as many people and organizations as possible. At this moment, the necessity of assuming the theoretical perspective of intervention according to the cultural and development level of a community appears. Initiating a social development strategy involves accepting changes that can often have significant effects on communities. To what extent the population supports such approaches will be observed throughout the implementation period.

The probability of development that we understand as social change in a positive or desired direction by community members is viewed with pessimism by authors such as Wallerstein (1991: 64), who asks questions about change in a sense desired by the initiators. The questions that may underlie such research clarify the theoretical principles, but do not go beyond the economic connotations of such an approach. Development planning implies "a positive change, it implies evolution, progress" 
(Precupețu, 2006: 45). This nuance allows to reduce the efforts to the change generated by a rational, objective and subordinate action to some objectives subordinated to the increase of the quality of life quality or of well-being.

Instead, the thinking of the classics signals that "the slow and continuous accumulations of these successive changes constitutes the social movement whose stages are usually marked by generations" (Carver, 1905: 35). The change in such a vision comes with the change of generations and what Carver calls "the renewal of adults". Thus, in accordance with the research objectives underlying this article, we have come up with two scenarios: the first refers to the changes that take place in a community under the influence of processes met in society and which contribute to the transformation of values, expectations and actions of the adult generations; the second scenario refers to the social structure of adult generations, consisting of age, population, occupations and specific value systems. Based on both scenarios we accept the social change due to the replacement of the generations. However, the findings of the current research show that the modernization of the society has produced a series of demographic imbalances in the process of replacing generations, with undesirable consequences on the evolution of small communities.

The historical perspective included in evolutionism allowed, in a first stage of the sociological reflection, to imagine a continuous line of positive social changes, in the sense of Spencer's (1898) thinking. This paradigm, shared by some optimistic groups today, is based on the idea that social organisms tend to evolve through the force of internal natural laws. The attempts to explain and even to discover immutable forms or principles of development (positive social changes) have generated a succession of theories that have evolved from the point of view of the covered issues and the depth of the explanations. Valade (1997: 355) accuses the tendency of periodic replacement of theoretical approaches without modifying the problems' approach. The same author pointed out to the increasing ideological stakes due to the controversies regarding the development strategies, their modernization and their equivalence with industrialization.

Conceptions about social change fall into the way in which change is perceived (Precupețu 2006: 46): as a directional path (in which we include evolutionism, neoevolutionism, historical materialism and modernization theories) or as a cyclical process by Spengler (1928) and Sorokin (1995). The research of social development implies a distinction in the adopted methodological model: systemic model or social field model. For the study of social change, in fact, generalizations of Comte's "social dynamics" and Spencer's "organisms" have been made.

According to Polish sociologist Piotr Sztompka (1993: 7), social change occurs on three levels: "starting from the macro level (international systems of nations, states), passing through the mezzo level (corporations, parties, religious movements, large associations) and up to the micro level (family, communities, groups, etc.)". From the point of view of elaborated theories, numerous limits can be found due to "the unequal highlighting of the endogenous and exogenous causes the contradictions inherent in a system, the technical, economic, cultural, political factors" (Valade, 1997: 356). The main weakness is that of failure in the opposition between traditional and industrial societies, regardless of the approach or the method. Valade specifies that this "stereotype representation" 
must be related to other antithetical couples, such as "immobility and change" or "structure and history", which will reduce the apparent complicity resulting from the usual approaches. Valade (1997: 357) recommends a conceptual clarification primarily in terms of terminology. Thus, innovation is considered the source of change. The industrial revolution becomes only a way of interpreting economic changes. For Valade, the social dynamic "is irreducible to the game several factors declared prevalent". The study of social development also involves the study of "resistance to change".

In a synthetic definition, development is considered to be "variations produced over time in ecological order of the population and communities in patterns of social roles and interactions, in the structure and functioning of institutions and the culture of societies" (Kornblum, 1988: 566; Jaffee, 1998: 3). The development of social change processes will be observed at several levels: at the individual, changes will concern attitudes and beliefs; at organizational level we will observe changes in the roles and patterns of interactions; at the social level, changes will be observed in the major institutions and in the emergence of demographic processes of migration from the rural to the urban environment (Jaffee, 1998: 3). These variations do not necessarily have a positive meaning, in accordance with the social objectives that contribute to the increase of the quality of life. But the meanings of the concept of social development are related to progress. According to Jaffee (1998), the Gross Domestic Product (GDP) is a development indicator used more often. This indicator measures the value of goods and services produced by a nation in a year. However, we should point out that this indicator gives the overall picture of the economy, without providing information regarding the internal disparities of each company. Also, measures to increase GDP can be based on partial policies, and the contribution to GDP can be unequal. This fact may be due to the internal disparities of a society which must be understood before elaborating development strategies. In this phase, we must understand the pre-existing social situation that requires change: underdevelopment, distorted development, and the actual process of social change, social development; preconditions, progress, intervention and the state that social development aims to reach (Midgley, 1995: 71).

Theoretical benchmarks highlight the need to clarify the concept. Theoretical foundations provide a way to initiate and organize social action, but the degree of success is conditioned by the expertise of the specialists involved. The European Union provides support for the implementation of development strategies without supporting a certain standard of intervention. We note that social development is associated with social change in a positive sense or more briefly with progress. The development process comprises a set of measures that include both economic, as well as social and cultural dimensions.

\section{Possibilities and principles for elaborating development strategies}

Starting from the previous theoretical benchmarks we find that innovation is a solution to a variety of problems that are difficult to meet by a standardized strategy. The ability to identify needs from the pre-existing period is coupled with the ability to discover one's own paths of action. In the first stage (of preexistence), it is necessary to orient a 
community or institution "towards achieving a desirable state, set as an objective to be achieved through a planned process in time, the result of a set of conjugate actions" (Zamfir, 2007: 173). Two structural components can be separated herein:

„a) an objective state, to be achieved by a community or social actor;

b) a set of actions carried out in time to achieve the respective objective: strategies, plans, programs" (Zamfir 2007, p. 173).

A development direction is identified in the "administration revolution" (Zamfir, 2007: 175), which consists in the translation of the administration through programs concurrent with decentralization. The positive effects of such an approach are found in the increase of creativity and "in the formulation of solutions, local participation and the creation of a local participatory democracy" (Zamfir, 2007: 175).

The application of social development principles can be found in community social development, as an effect of the different problems existing in rich and poor countries. In the case of developed countries, the problem of community social development is only marginal, while it is a major issue in poor and underdeveloped countries where "the fragility of the economic system systematically creates a deficit of opportunities for a major segment of the community to integrate into a global development process" (Zamfir, 2007: 176).

Along with the programs of local community development, actions were initiated to provide precise solutions for the population. Entities in social economy that can be classified into three categories have thus appeared: "cooperative enterprises, mutual societies and those organizations that can be generally described as associations whose legal classification can vary considerably from one country to another" (Stănilă, 2013: 15). Local development involves cooperation between the public, private and nonprofit sectors.

In Romania, the social economy "is considered to be social innovation because it is a complex process of introducing new programs and processes that change habits, perceptions and resources of the social policy system [...]" (Petrescu, 2013: 47). In ensuring the conditions of local development and for setting a favorable context, measures such as "functional institutional climate for local business, support for small and medium-sized enterprises can be included; encouraging the formation of new businesses; attracting foreign investment; investments in physical infrastructure, investments in «soft» infrastructure - the development of the workforce, the increase of the level of education, the creation of the legal and institutional-support framework granted to particular business clusters; support for disadvantaged areas of the localities" (Petrescu, 2013: 49).

The realization and elaboration of theories with concrete social successes implies the adoption of some principles (Jula et al., 2001: 8): “1) the principle of the unity of the national territory $[\ldots]$; 2) the principle of decentralization $[\ldots]$; 3) the principle of competence $[\ldots]$; 4) the principle of competition, of administrative non-intervention in carrying out economic processes..." In addition to these principles, there is also the need to respect "general rules and hypotheses with principle value" (Jula et. al., 2001: 8): 
„- principles for the analysis of arranged spaces (the principle of interdependence, the principle of asymmetry etc.);

- the rules that guide the process of elaborating regional strategies (defining the natural framework and the economic, social and political context, internal and external to the region, setting objectives, methods and means of achievement, defining the conditions of active cooperation with the local population etc.)".

The success of any development strategy becomes dependent on adherence to the principles that set out such an approach. The lack of an overall vision will limit the positive effects and will disorient and discourage the population.

\section{Models of Action}

Theoretical debates do not provide clarity on the path to be followed, but the development efforts of societies and the involvement of the civil society in their elaboration is a form of democratic action, by which social development becomes participatory (Zamfir, 2007: 175; Valade, 1998: 356). The general vision guiding the approach of community or regional development implies the adoption of the idea of modernization. Kabeer (1994: 16) defined modernization as "a process of evolutionary development, which moves societies from the pre-modern status to the final destination of modernity through a series of changes". By modernization, we mean a more complex process than development or than the simple social change due to the social dimensions and the assumed objectives. Overcoming the idea of improving economic conditions is, from this point of view, the basic principle of modernization.

Although the objectives are desirable, and the developed societies (with a high degree of modernity) attract numerous emigrants from underdeveloped countries, we notice that the latter have difficulties in modernizing the traditional structures through the imitation of the West, although this process is indicated as a solution by authors such as Inglehart and Baker (2000: 19), who noted that the general objectives between traditional and western societies are different: in the first case, objectives of material security and survival are pursued, and in the second case, objectives focus on "quality of life, environmental protection and self-expression".

Recalling that the structure of society at one point is the result of a long series of historical accumulations, it is hard to believe that this dissolution of traditional structures can be done over a single generation. The assumption of the decisive influence of the developed companies on the underdeveloped ones, in the sense of favoring the development, proves a step beyond reality. Bădescu (2004: 115) pointed out that the influence of advanced countries contributed to the "dissolution" of old structures, without contributing to the formation of new ones, which contradicts the theoretical presumption of positive influences.

The finding of a factual state implies the reflection on the intervention methods. It is a challenge for any specialist to imagine new structures to replace those dissolved by the imitation of the structures in developed countries. The main condition of a socioeconomic structure adapted to the modern global society is sustainability. Sustainability 
also involves the dynamics of new socio-economic structures, so as to meet the future needs of communities and regions, i.e. their internalization and harmonization with the value system of the population at a level that will perpetuate them from generation to generation. The solution of involving all social actors in the design of development strategies is a democratic form by which each person contributes to the configuration of his community and, implicitly, of his own future.

The LEADER approach comes in support of such a solution, which addresses the structures that have been the subject of the research presented in this article. In the light of this approach, the sustainable development of rural areas in Europe is desired, addressing economic, social and environmental problems. The principle that underpins the LEADER method is integrated into the range of solutions identified through the research carried out over time. Dissolutions of traditional structures, which do not offer the possibility of development, can only be compensated by external support. The reconfiguration of efficient socio-economic structures without external support is unlikely, given that the historical evolution of a community has been blocked by contact with more developed societies. In other words, "the sources of underdevelopment are internal, while the development solutions can only be external" (Vlăsceanu, 2001: 36). The LEADER method ensures the financing of the development programs initiated by local managers in partnership with local actors: civil society, business environment, citizens.

Following the research presented in this article, we wonder what the ideology that generates sustainable development is: economic, social or environmental? The emphasis on one dimension or another results from the approach of those involved, who may have ideological inclinations towards the area of social democracy or liberalism.

The identification of the real problems implies field studies adopting an "explanatory perspective" (Cace, 2004: 83) and focusing on:

„-- structure: the nature of the benefits sought and the divisions between the competing groups;

- or to actors, participating organizations, parties and ideologies."

From the matrices thus obtained, the opportunities offered by the LEADER method can be activated locally. The European Union's contribution as an external entity involved in limiting the negative effects of underdevelopment is highlighted by the seven essential features of the LEADER program (European Commission, 2006):

- „Area-focused local development strategies;

- Developing and implementing "bottom-up" strategies

- Local public-private partnerships: local action groups

- Multi-sectoral integrated actions

- Innovation

- Cooperation 
- Establishing network contacts".

These features bring the "principle of competence" (Jula et al., 2001: 8) to attention, which implies local solidarity, understanding the common interests and the capacity of local administration communities.

\section{Secondary Data Analysis}

The research was carried out within the framework of the actions for evaluating the implementation of the Local Development Strategies in the Local Action Groups "Colinele Olteniei" consisting of sixteen settlements from Dolj county and one from Mehedinţi county, "La Noi în Sat", consisting of eight settlements, six of which in Olt county and two in Dolj, and "Ținutul Cloșani" consisting of sixteen settlements in Mehedinți county.

Local Action Groups "Colinele Olteniei” and "Ținutul Cloșani” include very poor villages and settlements. The geographical scope partially covers three of the five counties of Oltenia, and within this chapter we draw conclusions resulting from the centralization of the answers obtained in all three groups. We consider that by analyzing the data collected for each entity we will have an image on the specific problems, as well as an overview of the respondents' attitude towards the LEADER approach. The three sociological surveys will provide information on the positive and negative aspects of the LEADER method.

The first objective of the research aimed at knowing the intervention logic of the Local Development Strategies. The first step in understanding the intervention logic indicates a first paradox: firstly, the problems indicated by the citizens referred to the lack of jobs, the emigration of young people, the aging population and the high degree of poverty of the population. It was discovered that the most important problems raised by citizens were economic and social. In all three local action groups we are dealing with a low degree of employment, high levels of emigration and an ageing remaining population. A factor generating the first three problems is the high degree of poverty of the population. An option related to the degree of comfort of the community (insufficient or non-existent utilities) ranks only fifth. This structure of the problems highlighted by the population reveals the orientation towards solving economic problems and survival.

The public administrative efforts to influence development show that the orientation of the members of the local action groups focused on investments in utilities, the consolidation of agricultural lands, the efficiency of public activities and the improvement of relations with the civic society. This parallelism between the manifest and the latent problems is favorable for the emigration of the young people and the decrease of the attractiveness of the area for the business environment. The ageing process will continue and only the economic success of the emigrants might improve the current context. Increasing the degree of collaboration with the civic society and the consolidation of agricultural lands are factors that announce the initiation of actions to improve the economic dimension and to take advantage of the possibilities opened by 
the partnerships between the public administration, the civic society and the business environment.

At the meetings of the local action groups, the priorities consisted of the attraction of new members and the implementation of measures from the Local Development Strategy. Projects have been implemented in all associated communities. Most of the finalized projects had as target the purchase of working equipment by the City Halls, the realization of the water supply, the asphalting and the rehabilitation of the roads and the arrangement of the local sports complexes. The social activities have a small share, with a very small percentage of the activities intended for the beneficiaries. However, the actions taken are gratifying for $65 \%$ of the citizens, who gave grades between 8 and 10 for the quality of the Local Development Strategies.

The second objective of the research looked at the coherence of the intervention logic. The main problem of coherent implementation of the Local Development Strategy is the reduced financial allocation, as mentioned by almost $70 \%$ of the respondents. Progress indicators have a high accuracy, according to the statements of $73.2 \%$ of the respondents. The results pursued by the Local Development Strategy are clearly defined for $53 \%$ of the respondents.

Respondent opinions show that the developed strategies are well defined, being easy to understand for the population, even in the cases of lack of specific specialization, from which the possibility of involving as many people as possible appears. The progress indicators are correlated with the results that could be obtained on the basis of insufficient funding.

The third objective of the survey referred to the achievement or to the probability of achievement of the strategy objectives. The positive appraisals of the local development strategies are due to the generous provisions. At present, there are non-agricultural activities, in most cases shops and bars, i.e. small commercial entities without a significant impact on the diversification of the labor market. Less than $30 \%$ of households in the three local action groups are led by young people who are farmers, but who still have small or very small chances to achievement in their local community. This observation (based on more than $50 \%$ of the respondents), correlates with signaling the insufficiency of the funds necessary to accelerate the modernization processes.

The fourth topic focused on knowing the benefits of the LEADER method. The evaluation indicated that the most important benefit induced by LEADER is the knowledge of the level of collaboration between the associated communities. The second benefit was the identification of topics of common interest. The third benefit was that of increasing the degree of trust between the member communities. The opinions expressed by the respondents highlighted that the degree of collaboration and mutual trust has increased. On the other hand, there was no transfer of good practices, nor did it exceed the moment of joint planning.

The fifth study item highlighted the factors that influence the local development strategies. The positive factors characteristic to the three local action groups are the agricultural potential, the involvement of the local public administration, the permanent 
access to information, the support in obtaining European financing and the successes in accessing the European funds. The negative factors with blocking effects in the implementation of development strategies are a difficult legislation and an exaggerated bureaucracy, youth emigration, reduced financial allocation and demographic decline.

By balancing positive and negative factors, we find that agricultural potential can be the basis for influencing the negative factors represented by emigration, demographic decline and population poverty. Future measures involve collaboration with those responsible for simplifying bureaucratic procedures and reducing the volume of requested documents, meetings with AFIR (Agency for Financing Rural Investments) representatives and members of local action groups. Also, the proposals advanced by the respondents refer to a more consistent support of new initiatives.

\section{Conclusions}

The assessments made at the beginning of 2019 highlighted that, in the situation of poor communities, we have to deal with a slow process, with a reduced dynamic towards community needs. The opinions expressed by the research participants indicated that the financial allocations were insufficient and the problems of the communities, such as the emigration of the young people who do not have opportunities to develop in their own communities and the ageing of the population resulting from the demographic decline, are negative factors that block or slow down the modernization.

These phenomena result from the inability of communities to replace their generations, a consequence of the lack of balance between generations, which is found in the persistence of traditional socio-economic structures. This context is favored even by the authorities' efforts to invest in utilities, water supply and road infrastructure, which is, building investments with indirect effects on the manifest problems of the locality. Modifying the demographic structure will contribute to the emergence of a values system. The demographic decline will be followed by a social decline and the economic growth efforts, which have been delayed, will be doomed to fail. The successes so far are marginal and uncorrelated with the immediate needs, being in fact latent problems, ignored for many years and approached sequentially in the activity of public administration.

Given the complexity of these issues, we appreciate that local development strategies should be aligned with strategies developed at both national and regional levels. Thus, both the financial needs and the intervention priorities can be calibrated in an efficient form. The social changes produced on the three levels are neither synchronous, nor correlated. Although, through the LEADER approach, the strategies that developed "bottom up" are supported, the changes in and the modernization of the Romanian society started in the opposite direction: from the bottom upwards. It seems that the slow pace of modernization of rural communities is, in many cases, late, and the dissolution of such rural communities is faster than the possibility of reconstruction.

A solution involves the coagulation of several factors that can contribute to the modernization of the rural environment. Local inhabitants pointed towards the 
agricultural potential as a direction of action for solving the problems of their communities. Thus, investments in the development of agriculture seem to be the fastest way to catalyze local energies in the foundation of long-term strategies and for generating added value on top of the European financing.

The LEADER method proves to be functional throughout the implementation area with the observation that the level of European funding is beneath the needs of the communities, and the coagulation of all existing forces is limited by the fact that, in Midgley's (1995) terms, the communities included in this research are in the pre-existing stage: the stage to identify the development needs and to know the preconditions which will establish the directions of action for long-term sustainable results. Currently, it can be observed that we are dealing with problems for which there are no solutions, but we are trying to find them. Thus, through the European funding and the association of communities with low resources, it could be possible to clarify the opinions regarding the existing problems and to elaborate some strategic measures.

\section{References}

Bădescu, I. (2004). Dezvoltare şi subdezvoltare. Contribuții la critica sociologiei tranziției. Sociologie Românească, 2(3), 108-128.

Cace, S. (2004). Statul bunăstării: evoluții și tendințe. Bucureşti: Editura Expert.

Carver, T.N. (1905). Sociology of Social Progress. Boston: The Athenaeum Press.

Inglehart, R., \& Baker, W. E. (2000). Modernization, cultural change, and the persistence of traditional values. American Sociological Review, 65(1), 19-51.

Jaffee, D. (1998). Levels of Socio-Economic Development Theory. Westport: Greenwood Publishing Group.

Jula D., Jula N., Ailenei D., \& Gârboveanu A. (2001). Competitivitate și dezechilibre regionale. In Simion, E. (coord.): Dę̧oltarea regională și integrarea europeană, Grupul de reflecție Evaluarea Stării Economiei Naționale, Academia Română. Available at URL: http://www.cide.ro/caiet_23.pdf, retrieved on July 2nd, 2019.

Kabeer, N. (1994). Reversed Realities: Gender Hierarchies in Development Thought. London/ New York: Verso.

Kornblum, W. (1988). Sociology in a Changing World. Harcourt College Publishers.

Midgley, J. (1995). Social development: The developmental perspective in social welfare. Sage. London: Sage Publications.

Petrescu, C. (2013). Dezvoltarea locală în România - rolul organizațiilor de economie socială în furnizarea de bunăstare. In Petrescu, C. (coord.): Economia socială în contextul deqvoltării locale. Iași: Polirom.

Precupețu, I. (2006). Strategii de dezvoltare comunitară. Iași: Expert Projects.

Sorokin, P. A. (1995). Social and cultural dynamics: a study of change in major systems of art, truth, ethics, law and social relationships. Boston: Porter Sargent Publishers, Inc.

Spencer, H. (1898). The Principles of Sociology. New York: D. Appleton and Company.

Spengler, O. (1928). The Decline of the West. New York: A.A. Knopf.

Stănilă, G. (2013). Economia socială și desvoltarea locală. In Petrescu, C. (coord.): Economia socială în contextul dezvoltării locale. Iași: Polirom.

Sztompka, P. (1993). The Sociology of Social Change. Oxford: Blackwell. 
Valade, B. (1997). Schimbarea Socială. În Boudon R. (coord.): Tratat de Sociologie. București: Editura Humanitas.

Vlăsceanu, L. (2001). Politică și dę̧voltare. România încotro? Bucureşti: Editura Trei.

Wallerstein, I. (1991). Untbinking Social Science. The Limits of Nineteenth-Century Paradigms. Cambridge: Polity Press.

Zamfir, C. (2007). Dezvoltare Socială. In Zamfir C., Stănescu, S. (coord.): Enciclopedia deqvoltării sociale. Iași: Polirom.

Comisia Euorpeană. Abordarea LEADER, europa.eu. URL:

https://ec.europa.eu/agriculture/publi/fact/leader/2006_ro.pdf, retrieved on August 8th, 2019. 